\title{
Eurosurveillance - fifteen years of serving Europe
}

A Nicoll (angus.nicoll@ecdc.europa.eu)1

1. European Centre for Disease Prevention and Control, Stockholm, Sweden

Citation style for this article:

Nicoll A. Eurosurveillance - fifteen years of serving Europe.

Euro Surveill. 2011;16(45):pii=20015. Available online: http://www.eurosurveillance.org/ViewArticle.aspx?Articleld=20015

The first edition of Eurosurveillance was published, in print and online, in September 1995 under the editorship of Jean-Baptiste Brunet of the Centre European pour la Surveillance Epidemiologique du CIDA in Paris. This pilot was funded by the European Commission and already had an editorial board with members from all countries in the European Union (EU). That single edition was used to test the feasibility of producing a European communicable disease journal and was part of a wider initiative under the informal EU Charter Group [1]. Distributed to 12,000 potential readers accompanied by a questionnaire, the 1995 experiment was greeted enthusiastically by the European infectious disease control community. This justified the launch of two linked projects that took off under a unified editorial board. A monthly journal edited by Brunet was started in Paris from mid-1996 in what became the Institute de Veille Sanitaire (InVS) in 1998, and in May 1997, a weekly journal edited by Noel Gill and Stuart Handysides started at the then Public Health Laboratory Service Communicable Disease Surveillance Centre (PHLS-CDSC) in London (Table).

Through a series of project grants from the European Commission and the enduring commitment of INVS and the PHLS-CDSC (later the Health Protection Agency) the monthly and weekly projects continued as separate outputs even after they became funded as a single EU project in 2000. The editorial board that grew as the numbers of countries in the EU and European Economic Area (EEA) increased. The next important step was taken in 2007 when, following the creation of the European Centre for Disease Prevention and Control (ECDC) in May 2005, a permanent home for the journal was established at ECDC in Stockholm. A smooth transfer was made possible by the out-posting of original Eurosurveillance staff from London. A crucial point was commitment to the journal's editorial independence granted by ECDC director Zsuzsanna Jakab and her successor in 2010, Marc Sprenger [2].

So what has changed over the decade and a half? In some ways not a lot, as the infectious diseases have remained the same. The first issue of Eurosurveillance in September 1995, the first Eurosurveillance monthly in 1996 and the first Eurosurveillance weekly 1997 featured topics such as cholera in Albania, a microbiological surveillance network for salmonellosis and shigellosis in Portugal, E. coli and haemolytic uraemic syndrome in Sweden and the Canary Islands, tuberculosis in Europe and blood-borne infections. Those remain threats in 2011, and articles on those topics have been published in Eurosurveillance this year. Not only diseases remain the same some some discussions related to public health never seem to go away: The 1995 edition comments on a lack of standardisation in immunisation schedules in Europe. New threats have appeared, and articles on antimicrobial infections and healthcare-associated infections have become more common, as have reports of emerging and re-emerging infections. However, the most notable change in the period since 2007 has been an extraordinary increase in the number and range of articles submitted and an expansion in the number and geographical distribution of readers and contributors in and outside Europe [3]. In the last three years (2009-2011) ca 600 articles have been published from 29 countries in the EU/EEA grouping and 148 from countries in the rest of the world*.

Four words define what is special about Eurosurveillance. Quality both scientific and editorial, speed and flexibility, and its network of people. Peer review is conducted rigorously to maintain the high scientific quality but the editorial staff also improve the article, especially helpful for the majority of authors for whom English is not the first language. However it is the speed and flexibility that make Eurosurveillance unique among peer-reviewed journals. Important events and can and have appeared as a scientifically reviewed and edited article a few days after they happen [4], and the editorial team and its network of highly motivated peerreviewers and authors are ready to accommodate the needs of very different situations. Frequent topical compilations of articles provide additional value, for example in 2011 on the outbreak of haemolytic uraemic syndrome in Germany and the relevance of Chagas disease in Europe.

Being hosted at ECDC, the journal benefits from the epidemic intelligence activities and discussions with 
the experts in house. During the 2009 influenza pandemic, the journal published a large number of timely articles on the topic. This was not just an editorial coup but a remarkable contribution to public health and to ECDC's regular pandemic risk assessments for Europe. Influenza pandemics are variable and the response and countermeasures have to be tailored if they are not to be counterproductive [5]. They are also notorious for changing and evolving over time and as they progress geographically. Rapid peer-reviewed

\section{TABLE}

Milestones of Eurosurveillance

\begin{tabular}{|c|c|}
\hline \multirow{3}{*}{1995} & $\begin{array}{l}\text { First issue of Eurosurveillance (online and print, the single issue published in 1995) - a pilot issue to assess the feasibility of } \\
\text { producing a European communicable diseases bulletin }\end{array}$ \\
\hline & $\begin{array}{l}\text { Set up and jointly funded by the European Commission, the Réseau national de santé publique (later, Institut de Veille } \\
\text { Sanitaire (InVS)) in Paris, France, and the Public Heath Laboratory Service (later, Health Protection Agency (HPA)) in London, } \\
\text { United Kingdom }\end{array}$ \\
\hline & Editor-in-chief: Jean-Baptiste Brunet \\
\hline \multirow[t]{2}{*}{$1996-2007$} & $\begin{array}{l}\text { Two complementary projects, Eurosurveillance monthly and Eurosurveillance weekly, with a shared board of national editorial } \\
\text { advisors from the European Union countries }\end{array}$ \\
\hline & First issue of Eurosurveillance monthly \\
\hline \multirow{2}{*}{1996} & $\begin{array}{l}\text { Project leader and managing editor : Jean-Baptise Brunet, Centre Européen pour la Surveillance Epidémiologique du Sida } \\
\text { (CESES), France }\end{array}$ \\
\hline & $\begin{array}{l}\text { - Peer-reviewed outbreak and surveillance reports, Euroroundups, dispatch reports, short reports } \\
\text { - Bilingual (French-English) print edition (6,000 copies distributed throughout Europe) and online multilingual bulletin } \\
\text { (English, Spanish, French, Italian, Portuguese) available on the CESES website }\end{array}$ \\
\hline \multirow{3}{*}{1997} & First issue of Eurosurveillance weekly \\
\hline & Project leader: Noël Gill, Public Health Laboratory Service (PHLS), United Kingdom \\
\hline & $\begin{array}{l}\text { - Short, timely and fast-tracked peer-reviewed articles (rapid communications) } \\
\text { - Available in English on the PHLS website }\end{array}$ \\
\hline \multirow[t]{2}{*}{1999} & Enlargement of the Eurosurveillance editorial board with Norway \\
\hline & Enlargement of the Eurosurveillance editorial board with Estonia \\
\hline \multirow[t]{2}{*}{2000} & $\begin{array}{l}\text { Official recognition of Eurosurveillance monthly as a scientific peer-reviewed journal: indexation in Medline and Scopus } \\
\text { Eurosurveillance becomes a single project combining timely and in-depth peer-reviewed reports on one website } \\
\text { (www.eurosurveillance.org) and with two editorial offices in Paris and London that publish the monthly and weekly edition, } \\
\text { respectively }\end{array}$ \\
\hline & Appointment of new Managing Editor: Jacques Drucker \\
\hline 2002 & Appointment of new Managing Editor: Gilles Brücker \\
\hline \multirow[b]{2}{*}{2004} & $\begin{array}{l}\text { New quarterly print compilation, including a selection of weekly articles (English only); end of the print issue of the monthly } \\
\text { release }\end{array}$ \\
\hline & $\begin{array}{l}\text { Enlargement of the Eurosurveillance editorial board, following the European Union enlargement, to include representatives } \\
\text { from Bulgaria, Cyprus, Czech Republic, Hungary, Latvia, Lithuania, Malta, Poland, Romania, Slovakia and Slovenia }\end{array}$ \\
\hline 2005 & $\begin{array}{l}\text { Formal agreement with the newly established European Centre for Disease Prevention and Control (ECDC) - which was } \\
\text { mandated to publish a weekly epidemiological bulletin - on a special working relationship: a member of the editorial team in } \\
\text { London seconded to the ECDC offices in Stockholm, Sweden, and an ECDC Associate editor appointed (Karl Ekdahl) } \\
\text { The monthly edition continues to be produced by the team at InVS in Paris }\end{array}$ \\
\hline 2006 & Establishment of the editorial office at ECDC in Stockholm \\
\hline \multirow{2}{*}{2007} & $\begin{array}{l}\text { Officially transferred to and published by ECDC } \\
\text { The publisher grants editorial independence to the editorial team }\end{array}$ \\
\hline & $\begin{array}{l}\text { Appointment of new Editor-in-chief: Karl Ekdahl } \\
\text { Appointment of new Managing Editor: Ines Steffens }\end{array}$ \\
\hline 2008 & $\begin{array}{l}\text { Merging the two editions (weekly and monthly) into one weekly edition that includes both rapid communications (formerly in } \\
\text { the weekly edition) and regular articles (formerly in the monthly edition) } \\
\text { Beginning of the collaboration with EpiNorth and signing of the first Memorandum of Understanding }\end{array}$ \\
\hline 2009 & $\begin{array}{l}\text { The journal was selected for coverage by Thomson Reuters and is indexed and abstracted in the Science Citation Index } \\
\text { Expanded (also known as SciSearch) and in the Journal Citation Reports/Science Edition, beginning with Volume 14(1) } 2009 \\
\text { Major role played by Eurosurveillance during the influenza pandemic in disseminating scientific information rapidly, so as to } \\
\text { enable public health action where needed }\end{array}$ \\
\hline \multirow[t]{2}{*}{2010} & $\begin{array}{l}\text { Eurosurveillance was accredited by the Health on the Net (HON) Foundation as adhering to the HON code of conduct } \\
\text { The quarterly print compilations are replaced by printed special issues and topical compilations of selected material from the } \\
\text { online issues }\end{array}$ \\
\hline & Indexed in Embase \\
\hline \multirow[t]{2}{*}{2011} & $\begin{array}{l}\text { A trademark for Eurosurveillance was recorded in the register of the Community Trade Marks by the Office for Harmonization } \\
\text { in the Internal Market }\end{array}$ \\
\hline & Appointment of new Editor-in-chief: Ines Steffens \\
\hline 2011 & Seminar to mark 15 years of Eurosurveillance to be held during the 2011 ESCAIDE conference \\
\hline 2012 & The journal's first impact factor, for 2011 , is expected to be allocated \\
\hline
\end{tabular}


publication of analyses was thus of paramount importance. The rapid turnover became known globally and by 10 August 2010, the official end of pandemic, over 120 papers had been published, mostly rapid communications peer-reviewed by two experts. However influenza is but one infection, and in 2010 and 2011 the focus moved on, especially in this year to E. coli 0104 and emerging resistance to antimicrobial drugs as well as re-emerging diseases in Europe such as West Nile virus infections and malaria.

So what would Eurosurveillance and its readers and authors deserve for a 15th birthday present, and what should happen next? An impact factor would be nice. The good news is that there will be one in 2012 [5]. This should help the journal to it attract the best articles within its scope, increase the readership further, have an impact on public health and thus become the leading European journal of infectious disease epidemiology, prevention and control.

* On 13 December 2011 the sentence 'In the last three years (2009-2011) ca 600 articles have been published from 32 countries in the EU/EEA grouping and 148 countries in the rest of the world.' was corrected to read '[...] from 29 countries in the EU/EEA grouping and 148 from countries in the rest of the world'.

\section{References}

1. Giesecke J, Weinberg J. A European Centre for Infectious Disease? Lancet. 1998;352(1308):1308.

2. Sprenger M. Visions for the next five years: ECDC as a sustainable and service-oriented organisation. Euro Surveill. 2010;15(19):pii=19564. Available from: http://www. eurosurveillance.org/ViewArticle.aspx?Articleld=19564

3. Steffens I, Ekdahl K. Eurosurveillance - keeping an eye on infectious diseases. Euro Surveill. 2010;15(1): pii=19452. Available from: http://www.eurosurveillance.org/ViewArticle. aspx?Articleld $=19452$

4. Scheutz F, Møller Nielsen E, Frimodt-Møller J, Boisen $\mathrm{N}$, Morabito S, Tozzoli R, et al. Characteristics of the enteroaggregative Shiga toxin/verotoxin-producing Escherichia coli $0_{104}: \mathrm{H}_{4}$ strain causing the outbreak of haemolytic uraemic syndrome in Germany, May to June 2011. Euro Surveill. 2011;16(24):pii=19889. Available from: http://www. eurosurveillance.org/ViewArticle.aspx?Articleld=19889

5. Nicoll A, Ammon A, Amato Gauci A, Ciancio B, Zucs P, Devaux I, et al. Experience and lessons from surveillance and studies of the 2009 pandemic in Europe. Public Health. 2010;124(1):14-23. 